\title{
Surveillance of Groundwater Quality Using Geographical Information System in Kannur District, India
}

\author{
Thangavelu Arumugam ${ }^{1 *}$, Praveen Krishna ${ }^{2}$, Sapna $\mathrm{K}^{3}$ \\ 1* Department of Environmental Engineering, Park College of Technology, Coimbatore, India \\ 2 Department of Environmental Science, Central University of Kerala, Kasaragod, India \\ 3 Department of Environmental Science, PSG College of Arts \& Science, Coimabatore, India
}

\begin{abstract}
Groundwater is an important role of the environment in natural resources. The major sources of groundwater contamination in this study were open discharges of domestic sewage, inadequate sewerage system, open defecation, septic tanks, soak pits, contaminated water pools, unorganized solid waste dumping and use of fertilizers, pesticides for agriculture deteriorated the condition. In this present study revealed that the physical and chemical characteristics of ground water in different areas of Kannur district in Kerala have been determined different seasons with respect to its suitability for drinking and agricultural purposes. For this study the groundwater samples were collected during pre-monsoon and post-monsoon seasons from 70 wells representing the entire the study area. The groundwater samples were analyzed for Physicochemical characteristics using standard techniques in laboratory and compared with standards. The samples were analyzed with reference to the WHO and BIS standards. The groundwater quality information of the entire study area have been prepared using statistical and GIS technique for all the parameters. This paper proved in GIS will be helpful for measuring, monitoring and managing the groundwater pollution in the study area and suggested to protect groundwater resources in the environment.
\end{abstract}

Keywords: Statistics, GIS, Groundwater, Physico- chemical parameters.

\section{INTRODUCTION}

Water is the elixir of life, a precious gift of nature to all living forms in the universe. In all biological activities require water as an essential part of the future in the survival is not possible in the absence of water. However, the recent year's water has become a scarce commodity in most parts of the world. Water plays a critical role in sustainable development schemes of everywhere. Fresh water is necessary for the maintenance of natural renewable capital. Integrated management of water across user groups, combined with conservation of the resource aids and environmental security helps prevent potentially detrimental inefficiencies, waste and pollution (Prasad, 2008).

Groundwater resources in many countries are coming under increasing threat from growing demands, wasteful use and contamination. Surface water resources are particularly vulnerable to 
pollution and are limited in magnitude. Groundwater resources are hidden and often poorly understood, but they are widespread, relatively easy to protect from contamination and their development potential is great. Groundwater is the primary source of water for drinking and irrigation. It is a unique resource, widely available, providing security against droughts and yet closely linked to surface water resources and hydrological cycle. It's reliable supply, uniform quality and temperature, relative turbidity and pollution free, minimal evaporation losses and low cost of development are attributes making groundwater more attractive when compared to other sources.

The groundwater resources are dynamic in nature as they grow with the expansion of irrigation activities, industrialization, urbanization etc. Population and economic growth have led to ever more demands on the world's groundwater resources and in many countries. There are already significant impacts due to inadequately regulated groundwater pumping and from pollution due to inadequate management. Especially in developing countries, these trends can lead to large socio-economic costs, often for the poor. In some part of the world, apart from the above causes of geological formation of rocks/soils and intrusion of saline water causes deterioration in the groundwater quality.

Some of the natural causes based on the agro ecological settings are black cotton soil areas of the state, dissolved salts are high, the coastal areas such as backwaters, estuaries and salinity levels are high, effluents from the leather industry have contaminated the groundwater, effluents from textile industry have affected the groundwater, sea water intrusion has taken place in some coastal areas due to over extraction of groundwater, excess application of fertilizers and pesticides has affected groundwater quality in certain pockets. The high levels of nitrates are observed in the western districts, naturally occurring fluoride and arsenic are serious problems particularly in the western districts of the state.

Groundwater is the most important natural resource required for drinking to many people around the world, especially in rural areas. The resource cannot be optimally used and sustained unless the quality of groundwater is assessed (Mouna et al., 2011). Groundwater greater significance as a resource for utilization under various sectors as it is a confined resource within the layer beneath the surface of the earth and supposedly less polluted due to limited interaction with atmospheric agents. The chemical alteration of the groundwater depends on several factors, such as interaction with solid phases, residence time of groundwater, seepage of polluted runoff water, mixing of groundwater with pockets of saline water and anthropogenic impacts (Dethier, 1988; Faure, 1998; Umar et al., 2006).

Babiker (2005) have appraised the quality of groundwater is important to ensure sustainable safe use of these resources. However, describing the overall water quality condition is difficult due to the spatial variability of multiple contaminants and the wide range of indicators that could be measured. This contribution proposes a GIS based groundwater quality index (GQI) which synthesizes different available water quality data $\mathrm{Cl}^{-}, \mathrm{Na}^{+}, \mathrm{Ca}^{2+}$ by indexing them numerically 
relative to the World Health Organization (WHO) standards. Ground water is a valuable natural resource that is essential for human health, socio-economic development and functioning of ecosystems (Zekster, 2000). The health concerns associated with chemical constituents of drinking-water differ from those associated with microbial contamination and arise primarily from the ability of chemical constituents to cause adverse health effects after prolonged periods of exposure. There are few chemical constituents of water that can lead to health problems resulting from a single exposure, except through massive accidental contamination of a drinking water supply. Moreover, experience shows that in many but not all such incidents, the water becomes undrinkable owing to unacceptable taste, odour and appearance (WHO, 2008).

Kharad et al., (1999) have studied that groundwater can be optimally used and sustained only when the quantity and quality is properly assessed. GIS has been used in the map classification of groundwater quality, based on correlating total dissolved solids (TDS) values with some aquifer characteristics (Butler et al., 2002) or land use and land cover (Asadi et al., 2007). Various studies have used GIS as a database system in order to prepare maps of water quality according to concentration values of different chemical constituents. Yammani (2007) have been intended that GIS is utilized to locate groundwater quality zones suitable for different usages such as irrigation and domestic. Babiker et al., (2007) has proposed a GIS based groundwater quality index method which synthesizes different available water quality data by indexing them numerically relative to the WHO standards.

Barber et al., (1996) have carried that GIS based studies to determine the impact of urbanization on groundwater quality in relation to land-use changes. Nas and Berktay (2010) have mapped urban groundwater quality in Koyna, Turkey, using GIS. Ahn and Chon (1999) studied groundwater contamination and spatial relationships among groundwater quality, topography, geology, landuse, and pollution sources using GIS in Seoul. Lawrence (2007) had been prepared a groundwater quality map in GIS successfully for Chennai city, Tamilnadu, India but a groundwater quality assessment in Dhanbad district, Jharkhand, India was much more difficult due to the spatial variability of multiple contaminants and wide range of indicators that could be measured.

Jamal Hassan (2014) have studied that groundwater data in GIS environment for better understanding the spatial distribution of each chemical parameter and mapping of the current situation of groundwater quality of tehsil Sheikhupura. The most important chemical parameters of groundwater like pH, Total Dissolved Solids, Hardness, Sulphate, Nitrate, Sodium, Potassium, Calcium, Chloride, Magnesium, Iron, Fluoride, Arsenic and Lead are selected and compared to the guideline values presented by world health organization (WHO, 2001). Thangavelu (2013) have estimated mapping the groundwater quality in Coimbatore city, India based on various physico-chemical parameters. The obtained data were subjected to descriptive statistical analysis also the computations were achieved with the use of statistical package for social sciences (SPSS) descriptive statistics were computed for every chemical parameter for each sampling 
location. The parameters computed include minimum and maximum values, mean, standard deviation, variance, skewness and kurtosis. All the parameters obtained for the various locations were compared with the various permissible limits of the parameters set by WHO (2011) in order to identify areas of problems in quality of drinking water.

Geographic information system (GIS) has emerged as a powerful tool for storing, analyzing and displaying spatial data, and using these data for decision making in several areas including engineering and environmental fields (Goodchild, 1993). It helps to integrate, analyze and represent spatial information and databases. Spatial interpolation is an essential feature of GIS. GIS base zoning of groundwater quality map may be used as a guideline for predicting the groundwater quality to new areas. The present study provides a guideline for solving water quality problem in Kannur district. In the present study, statistical methods and ground water quality parameters were analyzed Kannur district was prepared considering the ground water quality data using GIS mapping. The specific objectives of the study are using descriptive statistics to assess the database for identification of groundwater quality parameters, to analysis the various ground water quality parameters using GIS and to develop an integrated groundwater quality map of Kannur district using GIS.

\section{STUDY AREA}

\subsection{Location}

Kannur district is limited by Kasaragod district to the north, Kozhikode district to the south and Wayanad district to the south-east. The east district is bounded by the Western Ghats, which forms the border with Karnataka state district of Kodagu. The geographic overview of this district covers an area of 2966 sq.km bounded by the North latitudes $11^{\circ} 40^{\prime} 00^{\prime \prime} 12^{\circ} 20^{\prime} 27^{\prime \prime}$ and East longitudes $75^{\circ} 10^{\prime} 00^{\prime \prime}$ and $75^{\circ} 56^{\prime} 30^{\prime \prime}$. The district can be divided into three geographical regions highlands, midlands and lowlands. The altitude of the district ranges from 50-60 m above mean sea level (Figure 1).

The administrative divisions is treated as one Revenue Division and further divided into three taluks viz. Thalasseri, Kannur and Taliparamba and has 129 revenue villages. Kannur district has 81 Grama Panchayats and besides Kannur Corporation have five municipalities. There are nine blocks are viz. Kannur, Edakkad, Thalassery, Kuthuparamba, Iritty, Thaliparamba, Irukkur, Payyannur, Peravoor. The populations of this district has the year of 2011 total population of 2,523,003 of which male and female were 1,181,446 and 1,341,557 respectively. In 2001 census, Kannur has a population of 2,408,956 of which males were 1,152,817 and remaining 1,256,139 were female respectively. 


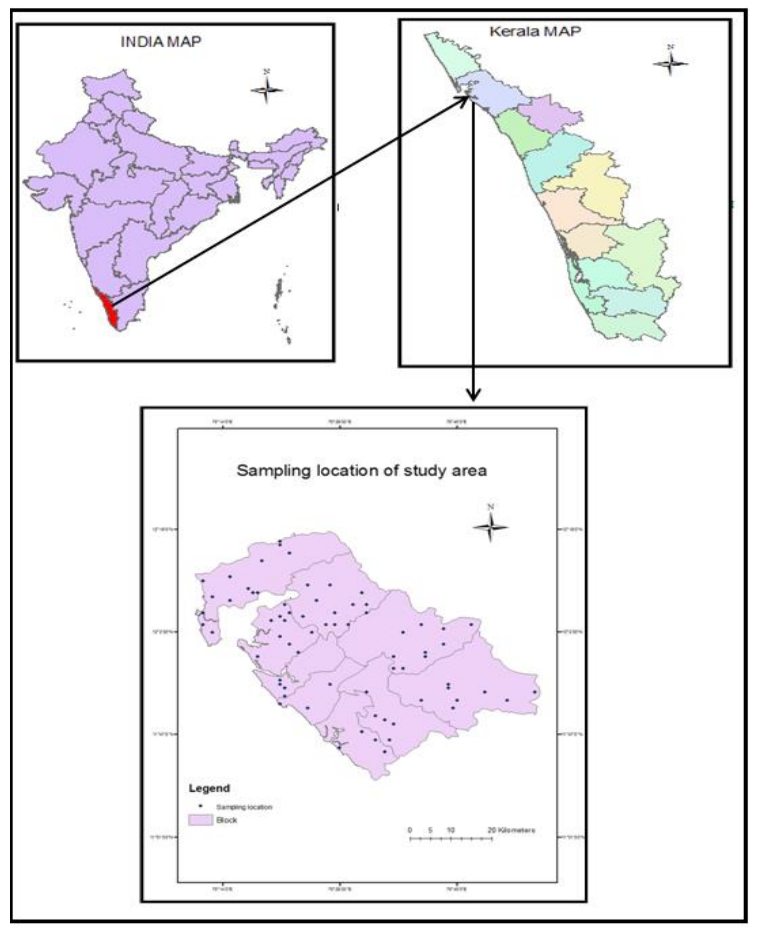

Figure 1. Study area map of Kannur district

The soil types can be classified as lateritic soil, coastal alluvium soil, riverine alluvium and brown hydromorphic soil and forest loam. The physical features based on the topography, geology, soils, climate and natural vegetation. Geologically the area is underlined by crystalline rocks of Archean group consisting of most part of Chernockites. The coastal area consists of coastal and alluvium, sand stone and clay with intercalation. Hydromorphic Saline soil in the coastal tract of the district especially at Cheruthazham, Kannapuram, Dharmadam areas are generally deep brownish in colour and poorly drained. Salinity is due to the inflow of tidal water in to this area through the network of the back waters and estuaries. It is mainly drained by the Valapattanam and Anjarakandy rivers. Valapattanam river is the longest in the district originates from Brahmagiri Reserve forest in Coorg district of Karnataka. The drainage area of the river in Kerala is 1321 sq.km. The district has a net annual ground water availability of 540.62 MCM with a net availability of $272.72 \mathrm{MCM}$ for the future use.

The existing gross ground water draft for irrigation $184.60 \mathrm{sq} . \mathrm{km}$, the existing gross ground water draft for domestic and industrial water supply 76.59 sq. $\mathrm{km}$, the existing gross ground water draft for all uses $261.69 \mathrm{sq} \mathrm{km}$, the total allocation for domestic and industrial requirement 
supply up to next 25 years 95.58 sq.km, the total net ground water availability for future irrigation development 272.72 sq. $\mathrm{km}$ and the total stage of ground water development $48.31 \%$ respectively. The district has three reservoirs which serve as surface water irrigation sources (CGWB, 2007).

\subsection{Methodology}

\subsection{Data}

For the present study, the groundwater data were collected from the quality and depth to water level data were obtained from Centre Water Resources Department and Management (CWRDM), Kozhikode. The data for the present study were collected from 70 locations from CWRDM board along with other parameters in three season data's in 2011 January, April and August two seasons in 2012 March and November 2012 are the years average present in respectively. The physico- chemical values of the 70 locations are not statistically significant between two seasons.

\subsection{Base Map}

Survey of India Toposheets 48M and 48P, (Scale of 1:50,000) from the survey of India, Bangalore were used to digitize the district boundary, taluk boundaries, drainages and forest layers.

1. The geology layers were prepared from the Geological Survey of India Map

2. The geomorphology map was prepared from Central Groundwater Board report

3. The groundwater physicochemical parameters was used to prepare the $\mathrm{Ca}^{2+,} \mathrm{Mg}^{2+}, \mathrm{Na}^{+}$and $\mathrm{K}^{+}$base maps

\subsection{Methodology}

\subsubsection{Sampling collection}

The groundwater samples from different bore wells were collected in eight out of nine blocks are Payyannur, Taliparamba, Edakkad, Kannur, Irikkur, Iritty, Thalasserry, Kuthuparambu and Peravur as per the guidelines of random sample method. For Physico- chemical analysis, Acid washed new one litre polythene bottles were used for collection of groundwater samples. Bore wells fitted with motors for water lifting were allowed to run the water for five minutes in order 
to flush out stationary water. Further, the sample cans were also flushed with several volumes of water before the collection of samples. The sample bottles are closed tightly and labeled. The samples were preserved, cooled and protected from breakage while transporting the bottles to the laboratory. After arrival to the laboratory, the groundwater samples were refrigerated at $4^{\circ} \mathrm{C}$.

\subsubsection{Sample analysis}

The water samples were used for physico-chemical parameters such as $\mathrm{pH}$, Electrical conductivity, Total Hardness, Total dissolved solids, Calcium, Magnesium, Sodium and Potassium used standard methods (APHA, 1995) adopted for each parametric analysis of groundwater samples. The water samples $\mathrm{pH}$ was measured with a potable $\mathrm{pH}$ meter. EC and TDS were determined using water analyzer. Turbidity was analyzed Turbidity meter. $\mathrm{TH}, \mathrm{Ca}^{2+}$ and $\mathrm{Mg}^{2+}$ were determined by EDTA titration, chloride is analyzed by argentometric titration. $\mathrm{Na}^{+}$and $\mathrm{K}^{+}$were measured in flame photometer chemical analysis. Inter relationship between chemical parameters were also studied by doing statistical analysis to understand groundwater quality.

\subsubsection{GIS Methodology}

GIS mapping analysis is a process, looking at geographic patterns of data and their relationship between features. The actual method used can be very simpler sometimes making a map, doing analysis involving complex models that mimic the real world by combining data layers. Some context for choosing parameters that might be required during the analysis. Geographic features are either discrete, continuous phenomena or summarized by area. At any given spot, whether the features are either present or not, continuous phenomena like precipitation can be found or measured. This phenomenon blankets the entire area and there is no gap in mapping. Continuous data starts out as a series of sample points that are regularly spaced or irregularly spaced (Tomlin, 1990). The GIS has subsystems to handle the data, of which three can be considered mandatory viz; data input/data manipulation and analysis, data output and display (Chrisman, 1997) shown as figure 2. 
The quality of the groundwater varies from place to place with the depth of water table. The ranges of each parameter along with observations/comments on groundwater quality presented in

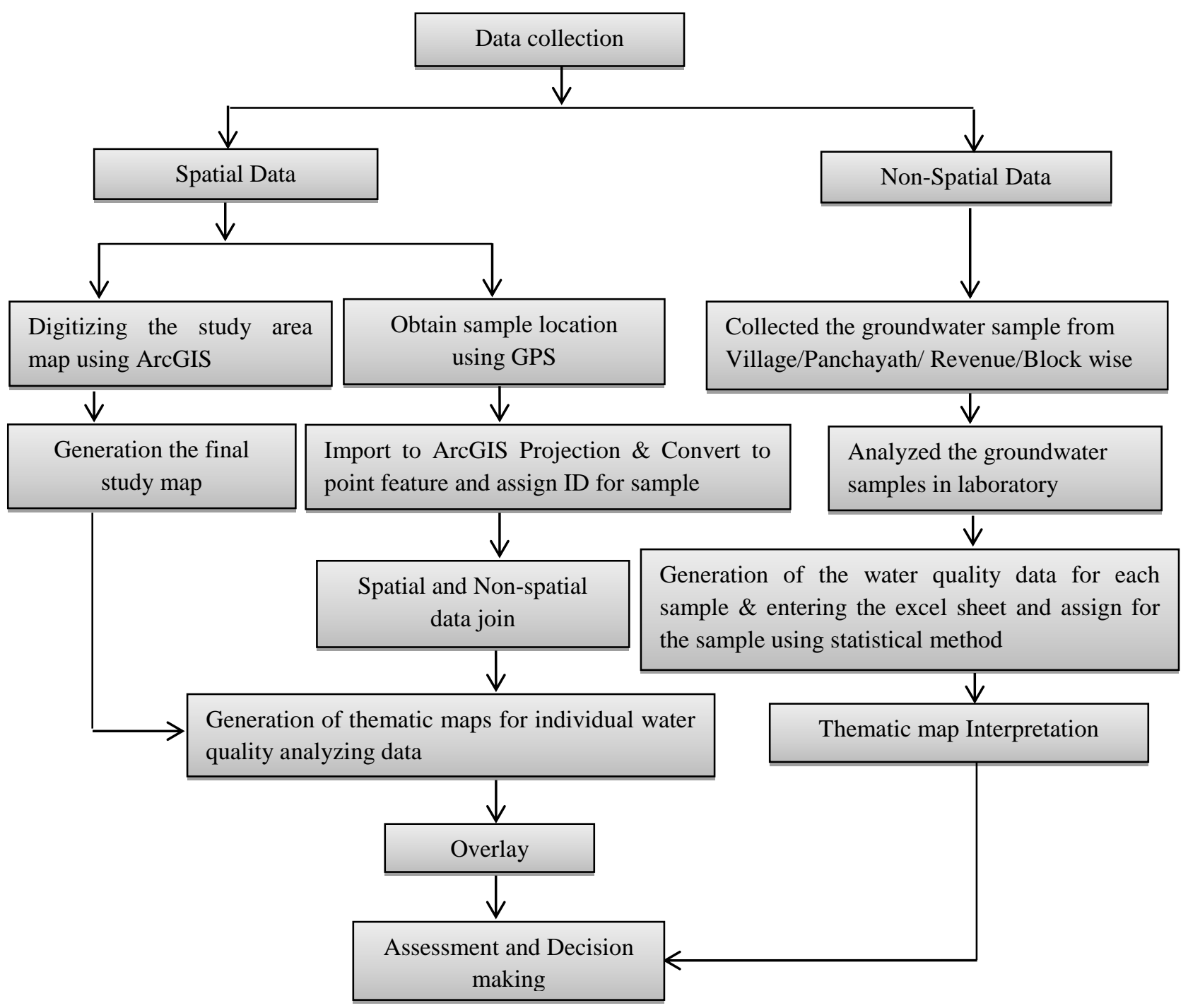

Figure 2. The flow chart showing the overall methodology of the study

\section{RESULTS}

\subsection{Descriptive statistical analysis of groundwater parameters in Kannur Distric}

The results of the physico-chemical parameters were analyzed and represented in Table 1. The following statistical parameters which include minimum, maximum, mean, median, standard deviation, skewness and kurtosis were studied. The analysis was carried out keeping view of the importance of the ground water quality which determines its suitability for agricultural, industrial purposes. The $\mathrm{pH}$ values of the groundwater ranges from 5.9 to 8.21 with an average of 7.30 during the year of 2011-2012. The total hardness values range from 18.11 to $181.77 \mathrm{mg} / \mathrm{l} \mathrm{during}$ 
the year 2011- 2012 with an mean average of 5.92. The alkalinity was also observed from the data which ranges from 7.17 to $167 \mathrm{mg} / \mathrm{l}$. The TDS values range from 24.63 to $295.92 \mathrm{mg} / \mathrm{l}$ during the year 2011- 2012 with an average of mean value 103.54. The Carbonate value ranged between 0.26 to $9.39 \mathrm{mg} / \mathrm{l}$ with an average of 1.61 during the year of present study. The Bicarbonate value ranged between 8.75 to $184.64 \mathrm{mg} / \mathrm{l}$ with an average of 5.61 .

The chloride value ranged between 8.32 to $54.42 \mathrm{mg} / \mathrm{l}$ with an average of 1.94 during the same period. Sulphate, nitrate, calcium, magnesium, sodium and potassium values were presented in data respectively. The analytic results of physico-chemical parameters were compared World Health Organization standards (WHO, 2006) and Bureau of Indian Standards (BIS, 2003) for drinking and public health purposes. It is observed that the values obtained strongly reflect that the key parameters were well below the recommended limits in Table 2.

\subsection{Integrated spatial analysis of groundwater quality in Kannur district}

GIS is used to evaluate the quality of ground water in Kannur district. Spatial variation map of major water quality parameters like pH, TH, Alkalinity, TDS, Carbonate, Bicarbonate, Chloride, Sulphate, Nitrate, Calcium, Magnesium, Sodium and Potassium were prepared for Kannur district based on these spatial variation maps of major water quality parameters and integrated ground water quality map of Kannur district was prepared using GIS. This integrated the spatial analysis of ground water quality maps helps us to know the existing ground water condition of the study area.

\section{Turbidity}

The quality of water is ascertained based on the turbidity value. The very high values of blocks are Payyannur and Irikkur (0.16 - 0.2). The moderate value of block is Kannur (0.15 -0.16). The low range of turbidity is obtainable in blocks are Taliparamba, Peravoor, Koothuparamba and Iritty $(0.106-0.152)$. The very low range of turbidity is presented in blocks are Thalassery and Edakkad (0.092-0.106) shown in Map 1.

\section{Hydrogen Ion (pH)}

The $\mathrm{pH}$ is used to determine whether a solution is acidic or alkaline. It is the expression of hydrogen ion concentration, the hydrogen ion activity more precisely. Total $\mathrm{pH}$ is an important parameter in assessing the water quality. Acidic conditions will prevail as $\mathrm{pH}$ value decreases 
and alkaline conditions will prevail as the $\mathrm{pH}$ value increases. The BIS and WHO limit for drinking water is $7.0-8.5$ shown in Table 2 . The low $\mathrm{pH}$ does not cause any harmful effect of the water. The high values of $\mathrm{pH}$ in $(7.34$ - 7.48) presented in block is Thaliparamba. The moderate values of $\mathrm{pH}$ in (7.27 - 7.34) presented in blocks are Payyanur, Irikkur and Peravoor. The low values of $\mathrm{pH}$ in (7.05 - 7.27) presented in blocks are Kannur, Thalaserry and Iritty. The very low value range of $\mathrm{pH}$ in (6.99-7.05) presented in blocks are Edakkad and Koothuparamba. The results show that all the water samples were within permissible limits as Map 2.

\section{Electrical conductivity (EC)}

\begin{tabular}{|c|c|c|c|c|c|c|c|c|c|c|}
\hline Parameters & $\mathrm{N}$ & Range & Min & Max & Sum & Mean & S.D & Variance & Skewness & Kurtosis \\
\hline $\mathrm{pH}$ & 70 & 2.25 & 5.96 & 8.21 & 5.11 & 7.3 & 0.57 & 0.32 & -0.26 & -0.56 \\
\hline $\mathrm{EC}$ & 70 & 452.2 & 41 & 493.2 & $\begin{array}{c}12068 . \\
8\end{array}$ & $\begin{array}{c}172.4 \\
1\end{array}$ & $\begin{array}{c}86.5 \\
2\end{array}$ & 7485 & 1.16 & 1.81 \\
\hline $\mathrm{TH}$ & 70 & 1.68 & 1.41 & 1.82 & 4.14 & 5.92 & 3.32 & 1104 & 1.5 & 2.81 \\
\hline Alkali & 70 & 1.60 & 7.17 & 1.67 & 3.41 & 4.87 & 3.41 & 1165 & 1.42 & 2.23 \\
\hline $\mathrm{TDS}$ & 70 & 271.29 & $\begin{array}{c}24.6 \\
2\end{array}$ & $\begin{array}{c}295.9 \\
2\end{array}$ & $\begin{array}{c}7247.4 \\
103.5\end{array}$ & $\begin{array}{c}51.8 \\
5\end{array}$ & 2688 & 1.16 & 1.82 \\
\hline $\mathrm{CO}_{3}^{2-}$ & 70 & 9.39 & 0 & 9.39 & 1.13 & 1.61 & 2 & 3.99 & 1.83 & 3.53 \\
\hline $\mathrm{HCO}_{3}{ }^{-}$ & 70 & 1.76 & 8.75 & 1.85 & 3.93 & 5.61 & 3.79 & 1437 & 1.37 & 2.05 \\
\hline $\mathrm{Cl}^{-}$ & 70 & 4.61 & 8.32 & 5.44 & 1.36 & 1.94 & 9.86 & 97.31 & 1.55 & 2.03 \\
\hline $\mathrm{SO}_{4}{ }^{2-}$ & 70 & 3.36 & 0.25 & 3.38 & 3.83 & 5.47 & 7.02 & 49.22 & 2.53 & 6.29 \\
\hline $\mathrm{NO} 3$ & 70 & 5.9 & 0.09 & 5.99 & 1.09 & 1.56 & 1.24 & 1.53 & 1.31 & 1.85 \\
\hline $\mathrm{Ca}$ & 70 & 4.22 & 2.26 & 4.44 & 9.93 & 1.42 & 8.83 & 78.02 & 1.44 & 2.28 \\
\hline $\mathrm{Mg}$ & 70 & 1.91 & 1.96 & 2.11 & 4.12 & 5.88 & 3.81 & 14.51 & 1.8 & 3.92 \\
\hline $\mathrm{Na}$ & 70 & 2.44 & 3.28 & 2.77 & 7.66 & 1.09 & 5.41 & 29.23 & 1.11 & 0.88 \\
\hline
\end{tabular}




\begin{tabular}{|l|l|l|l|l|l|l|l|l|l|l|}
$\mathrm{K}$ & 70 & 1.95 & 0.43 & 1.99 & 2.90 & 4.14 & 3.49 & 12.15 & 2.27 & 6.96 \\
\hline
\end{tabular}

The ability of a solution to conduct an electrical current is governed by the migration of solutions and is dependent on the nature and numbers of the ionic species in that solution. This property is called electrical conductivity. It is a useful tool to assess the purity of water. EC collected groundwater samples ranged from 41 to $493.2 \mu \mathrm{S} \mathrm{cm}^{1}$. The EC is very high values of blocks are Thalassery, Koothuparamba and Kannur (168.50-217.35). The moderate value of EC presented blocks are Taliparamba, Iritty and Peravoor (143.8-168.32). The low values of EC observed in blocks are Payyannur and Irikkur (129.85-154.38) and very less value in Edakkad block. EC is a good indication of total dissolved solids which is a measure of salinity that affects the taste of potable water. Several factors like temperature, ionic mobility and ionic valences also influence the conductivity. The permissible limit for EC is $300 \mu \mathrm{S} \mathrm{cm}{ }^{1}$ shown as Map 3.

Table 1. Physico-chemical parameters of ground water samples in study area

\section{Total Hardness (TH)}

Hardness is the property of water which prevents the lather formation with soap and increases the boiling points of water (Trivedy and Goel, 1986). Total hardness of water mainly depends upon the amount of calcium or magnesium salts or both. The hardness values shown range from $37.87 \mathrm{mg} / \mathrm{l}$ to $67.29 \mathrm{mg} / \mathrm{l}$. The $\mathrm{TH}$ value is high range of value $(62.04-67.29)$ is presented blocks are Payyannur, Irrikkur and Thalassery. The TH value is moderate range of value ((55.00 - 62.04) is presented blocks are Taliparamba, Kannur and Iritty. The TH value is low range of value (37.87 - 55.00) is presented blocks are Koothuparamba and Peravoor and very low range of value ( 0 - 37.87) is presented blocks is Edakkad shown as Map 4.

\section{Total dissolved solids (TDS)}

The total dissolved solids in water are due to the presence of sodium, potassium, calcium, magnesium, manganese, carbonates, bicarbonates, chlorides, phosphate, organic matter, and other particles in the water. Ascertain the suitability of ground water for any purposes, it is essential to classify the ground water depending upon their hydro-chemical properties based on their TDS Values. The values of the total dissolved solids for all the groundwater samples vary between 11.11 and $101.09 \mathrm{mg} / \mathrm{l}$. The maximum permissible limit of total dissolved solids in groundwater for domestic purpose is $500 \mathrm{mg} / \mathrm{l}$ (WHO). TDS is very high in range in block of Thalassery. TDS values of moderate range (77.96 - 101.09) in blocks are Taliparamba, Peravoor, 
Kannur, Payyannur and Iritty. The low value of range (11.66-77.98) in block of Edakkad and very low range (11.11-11.6) presented in Irikkur and Koothuparamba. According to classification of drinking water on the basis of TDS values, all the groundwater samples are found to be non-saline shown as Map 5.

\section{Carbonate $\left(\mathrm{CO}^{2-}\right)$}

Carbonate values are not found in the groundwater sample, this may be due to the low $\mathrm{pH}$ value and the same result was observed in WHO. The $\mathrm{CO}_{3}{ }^{2-}$ range is (1.85-2.17) high blocks are Iritty and Kannur. The moderate $\mathrm{CO}_{3}{ }^{2-}$ range is (1.20-1.85) presented in blocks are Payyannur, Taliparamba, Irikkur and Edakkad. The low value of (1.016-1.200) $\mathrm{CO}_{3}{ }^{2-}$ in block is observed in Thalassery. The very low range is $(0.820-1.018) \mathrm{CO}_{3}{ }^{2-}$ in blocks are Koothuparamba and Peravoor. The carbonate values for most of the groundwater samples are well within the permissible limit $(75 \mathrm{mg} / \mathrm{l})$ as per the BIS and WHO guidelines shown as Map 6.

\section{Bicarbonate $\left(\mathrm{HCO}_{3}^{-}\right)$}

Bicarbonate values are not found in the groundwater sample, this may be due to the low $\mathrm{pH}$ value and the same result. The $\mathrm{HCO}_{3}{ }^{-}$range is (57.45 - 61.47) high blocks are Taliparamba, Iritty and Irikkur. The moderate $\mathrm{HCO}_{3}{ }^{-}$range is (53.51 - 57.45) presented in block is Kannur. The low values of (43.96 - 53.55) $\mathrm{HCO}_{3}{ }^{-}$in blocks are observed in Thalassery, Peravoor and Payyannur. The very low range is (40.35 - 43.96) bicarbonate blocks are Koothuparamba and Edakkad. The carbonate values for most of the groundwater samples are well within the permissible limit (75 $\mathrm{mg} / \mathrm{l})$ as per the BIS and WHO guidelines shown as Map 7.

\section{Chloride $\left(\mathrm{Cl}^{-}\right)$}

The value of chloride for all the groundwater samples is ranged from $15.31-30.58 \mathrm{mg} / \mathrm{l}$. Most of the groundwater samples indicated chloride values within the acceptable limit (250 mg/l) of BIS and WHO standards. Chloride is one of the most important parameter in assessing the water quality and higher concentration of chloride indicates higher degree of organic pollution. The presence of Chloride in water indicates saltiness. Chloride in excess of 100mg/l imparts a salty taste. In our result part of the value Koothuparamba block has high range of chlorine (24.2530.58). Thalassery and Kannur blocks are moderate Chlorine value (19.99-24.25). The low values of chlorine (16.96-19.99) presents in blocks are Irikkur, Iritty and Peravoor. The very low value of range is (15.31-16.96) presented in blocks are Payyannur, Thalassery and Edakkad 
shown as Map 8. The increase of chlorine level in water is injurious to people suffering due to heart and kidney diseases.

\section{Sulphate $\left(\mathrm{SO}_{4}{ }^{2-}\right)$}

Sulphate occurs naturally in water as a result of leaching from gypsum and other common minerals also present in water. Mostly the discharge of industrial wastes and domestic sewage tends to increase its concentration. The sulphate values for the groundwater samples are exhibited between 2.45 and $9.25 \mathrm{mg} / \mathrm{l}$. The sulphate values for all the groundwater samples are well within the permissible limit $(200 \mathrm{mg} / \mathrm{l})$ of WHO. The high range of value in sulphate (7.18-9.25) is presented in block is Kannur and Thalassery. The moderate range of value sulphate is (4.54-7.18) presented in blocks are Irikkur and Peravoor. The low value of range sulphate (2.45-4.54) is presented in blocks are Iritty, Koothuparamba, Payyannur and Taliparamba. The low range of sulphate (0-2.45) is presented in Edakkad block shown as Map 9.

\section{Nitrate $\left(\mathrm{NO}_{3}^{-}\right)$}

Nitrate is another component in water present the change the taste of water. Nitrite is also a Nitrogen compound with two molecules of Oxygen. It occurs with Nitrates in association with other compounds. The value of nitrate in all the groundwater sampling locations is found between 1.12 and $3.6 \mathrm{mg} / \mathrm{l}$ (Table 2). The acceptable limit of nitrate is $45 \mathrm{mg} / \mathrm{l}$ according to BIS and $50 \mathrm{mg} / \mathrm{l}$ to WHO. The high range of value in nitrate $(2.64-3.60)$ is presented in block is Irikkur. The moderate range of value nitrate is $(1.50$ - 2.64) presented in blocks are Iritty, Peravoor and Taliparamba. The low value of range nitrate (1.27-1.50) is presented in blocks are Iritty, Peravoor and Taliparamba. The low range of nitrate (1.12-1.27) is presented in Payyannur and Edakkad shown as Map 10. The presence of nitrate in groundwater may be due to leaching of nitrate with the percolating water. The contamination of groundwater may be due to sewage and other wastes rich in nitrates. Toxicity of nitrates in infants causes methaemoglobiaemia (USEPA, 2012).

\section{Calcium $\left(\mathrm{Ca}^{2+}\right)$}

Calcium dissolved readily from carbonate rocks and lime stones from soils. However, the calcium is an essential nutritional element for human being and helps in the maintaining the structure of plant cells and soils. In this study, the estimated calcium values are recorded between 9.9 and $19.5 \mathrm{mg} / \mathrm{l}$. For most of the groundwater samples are presented in high calcium range of 
value is (14.90 - 19.12) presented in blocks are Thalassery and Koothuparamba. The moderate calcium range of value (11.90 - 14.90) is observed in blocks are Taliparamba, Kannur, Peravoor, Iritty and Irikkur. The low value of calcium range (9.99 - 11.90) is presented in block is Payyannur and very low value calcium range of $(0$ - 9.99) is Edakkad block shown as Map 11.

\section{Magnesium $\left(\mathrm{Mg}^{2+}\right)$}

The magnesium values are recorded between 3.2 and $7.10 \mathrm{mg} / \mathrm{l}$ for the groundwater samples. The highest value of magnesium is observed the range (6.20-7.00) is Irikkur block. The moderate value of magnesium is presented the range (4.73-6.20) is Payyannur, Taliparamba, Kannur, Peravoor and Iritty blocks. The low value of magnesium is obtained the range (3.12-4.73) is Thalassery and Koothuparamba blocks. Edakkad block have very less range of magnesium (3.2). On comparison with the WHO standard value of magnesium, in this study it is confirmed that the magnesium value for all the groundwater sample is within the maximum permissible limit (50 $\mathrm{mg} / \mathrm{l})$. The spatial distribution map of magnesium ion concentration in groundwater of the study area is shown in Map 12.

\section{Sodium $\left(\mathrm{Na}^{+}\right)$}

Sodium and potassium are naturally occurring elements in groundwater. These two elements are directly added into groundwater from industrial and domestic wastes and contribute salinity of water. The value of sodium for the groundwater samples is recorded in the range of $7.89-16.75$ $\mathrm{mg} / \mathrm{l}$. The highest value of sodium is recorded Kannur block and moderate value of sodium is observed Koothuparamba, Thalassery and Peravoor blocks, low value of sodium presented in Payyannur, Taliparamba, Edakkad and Iritty blocks, very low of sodium observed in Irikkur block. From this study, it is confirmed that the value of sodium for the groundwater sample is well within the permissible limit (200 mg/l) suggested by WHO. High concentration of sodium ion in drinking water may cause heart problems and High sodium ion in irrigation water may cause salinity problems. The spatial distribution map of sodium concentration in groundwater of the study area is shown in Map 13.

Table 2: Comparison of ground water quality of the study area with WHO and BIS limit

\begin{tabular}{|c|c|c|c|c|}
\hline \multirow{2}{*}{ Parameter } & \multicolumn{2}{|c|}{ Range } & \multirow{2}{*}{ BIS } & WHO \\
\cline { 2 - 3 } & Min & Max & & \\
\hline Turbidity (NTU) & 0.06 & 4.20 & 1 & 5 \\
\hline
\end{tabular}




\begin{tabular}{|l|c|c|c|c|}
\hline $\mathrm{pH}$ & 5.96 & 8.21 & $6.5-8.5$ & $6.5-8.5$ \\
\hline $\mathrm{EC}((\mu \mathrm{s} / \mathrm{cm})$ & 6.14 & 493.20 & 300 & 500 \\
\hline $\mathrm{TH}(\mathrm{mg} / \mathrm{l})$ & 18.11 & 181.77 & 200 & 0.3 \\
\hline $\mathrm{TDS}(\mathrm{mg} / \mathrm{l})$ & 24.63 & 295.92 & 500 & 500 \\
\hline $\mathrm{CO}_{3}^{2-}(\mathrm{mg} / \mathrm{l})$ & 0.25 & 9.39 & 75 & 75 \\
\hline $\mathrm{HCO}_{3}{ }^{-}(\mathrm{mg} / \mathrm{l})$ & 8.75 & 184.64 & 30 & 150 \\
\hline $\mathrm{Cl}^{-}(\mathrm{mg} / \mathrm{l})$ & 8.32 & 54.42 & 250 & 250 \\
\hline $\mathrm{SO}_{4}^{2-}(\mathrm{mg} / \mathrm{l})$ & 0.25 & 33.84 & 200 & 250 \\
\hline $\mathrm{NO}_{3}{ }^{-}(\mathrm{mg} / \mathrm{l})$ & 0.09 & 5.99 & 45 & 50 \\
\hline $\mathrm{Ca}^{2+}(\mathrm{mg} / \mathrm{l})$ & 2.26 & 44.43 & 75 & 100 \\
\hline $\mathrm{Mg}^{2+}(\mathrm{mg} / \mathrm{l})$ & 1.96 & 21.08 & 30 & 50 \\
\hline $\mathrm{Na}^{+}(\mathrm{mg} / \mathrm{l})$ & 3.28 & 27.66 & 50 & 200 \\
\hline $\mathrm{K}^{+}(\mathrm{mg} / \mathrm{l})$ & 0.43 & 19.94 & - & 200 \\
\hline
\end{tabular}

\section{Potassium $\left(\mathrm{K}^{+}\right)$}

The major source of potassium in natural fresh water is weathering of rocks but the quantities increase in the polluted water due to disposal of waste water (Trivedy and Goel, 1986). The potassium values for the groundwater samples are observed between 3.23 and $6.12 \mathrm{mg} / \mathrm{l}$. The high value of range in Potassium (5.61-6.12) is observed in blocks are Thalassery and Kannur. The moderate value of range in Potassium (4.09-5.61) is presented in blocks are Payyannur and Peravoor. The low range of potassium (3.61-4.09) is present in Iritty block and very low range in Potassium in (3.23-3.61) is detected in Taliparamba, Edakkad and Irikkur blocks. On comparison with the WHO standard value, it is found that the potassium values for all the groundwater samples are well within the maximum permissible limit $(100 \mathrm{mg} / \mathrm{l})$. Spatial distribution map of potassium concentration in groundwater of the study area is shown Map 14. 

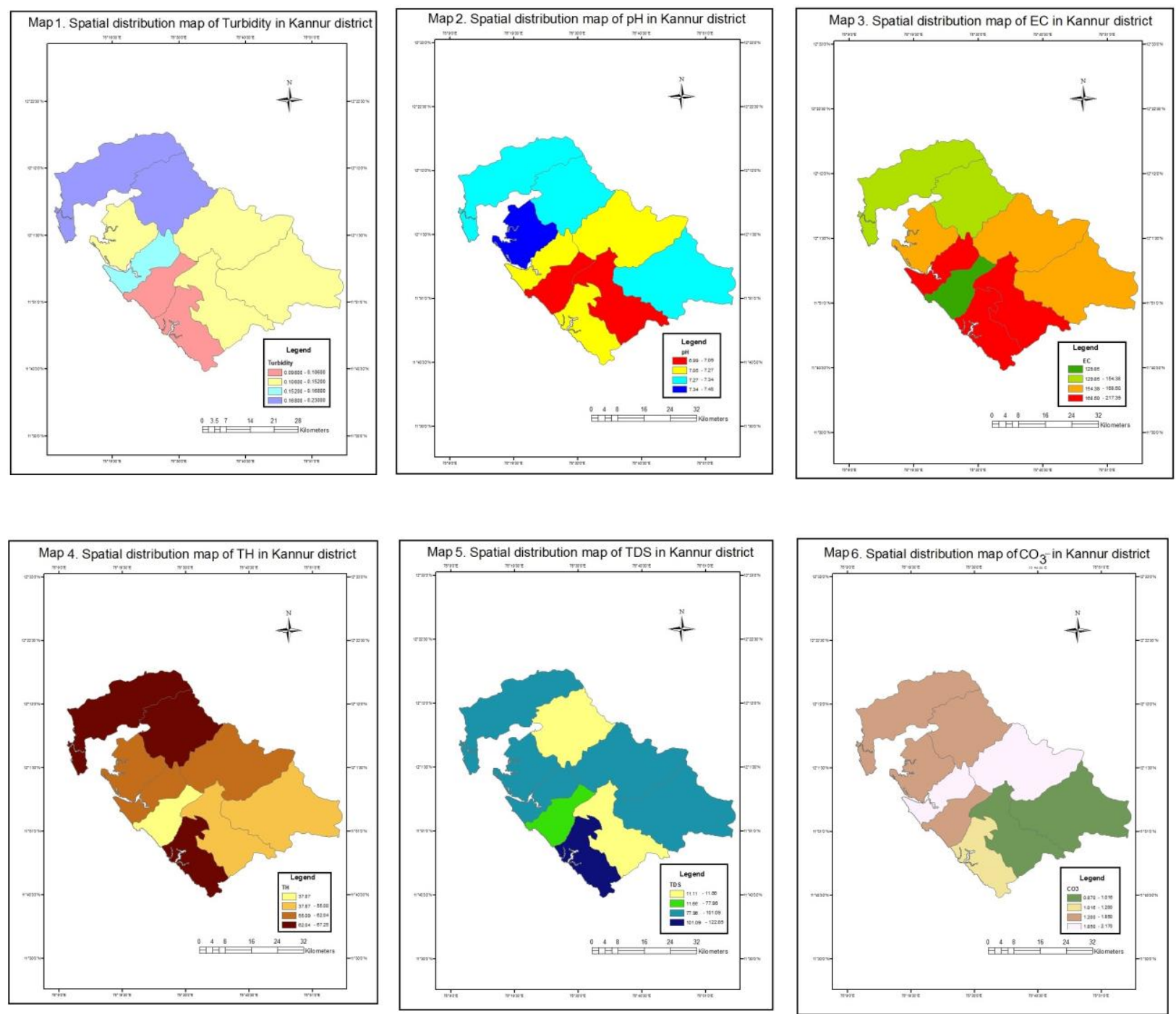

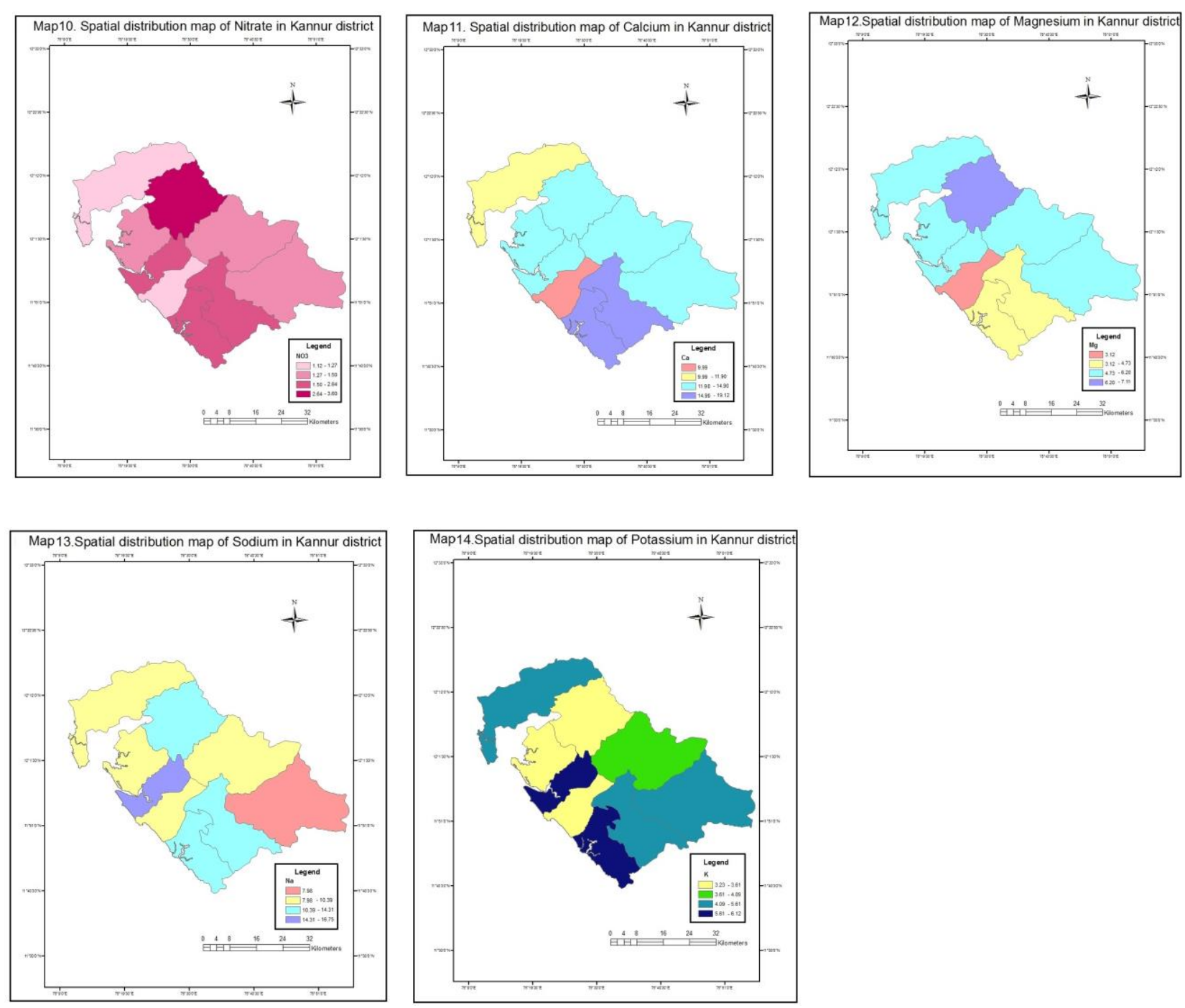


\section{CONCLUSION}

In the present study, an attempt was made to evaluate and produced for the map of groundwater quality of Kannur district. The spatial variation map of the major water quality parameters like Turbidity, pH, EC, TDS, TH, Sulphate, Chloride, Carbonate, Bicarbonate, Calcium, Magnesium, Sodium, Potassium and Nitrate were prepared for Kannur district based on these spatial variation maps of major water quality parameters and integrated ground water quality map. This integrated ground water quality map helps us to know the existing ground water condition of the study area. The study was carried out in entire study area using GIS technology, it can be provide appropriate platform for convergent analysis of large volume of multi-disciplinary data and decision making for ground water studies can be effectively done. The study area is under threat due to the critical issues of environmental pollution and water scarcity problems. The groundwater quality in this district has been reduced due to pollution. Hence the monitoring of the groundwater quality is indispensable in groundwater pollution. The groundwater quality map may be used as a guideline for predicting the groundwater quality to new areas. In this study provided a guideline for solving water quality problem in Kannur district.

Groundwater quality in any area depends on the concentration of major ions, minor ions and trace elements constituents. In present study, the groundwater quality investigation carried out indicates that the quality of groundwater is not affected with regard to major ions in the time of period. There are no other studies carried out from this area have reported adverse effect of major ions on groundwater quality in this study area. According to this study, the ground water quality in WHO permissible limit of turbidity value is 5 NTU. In the map 1, analyzed the maximum value of turbidity value noticed from 0.23 NTU. So there is low value of the turbidity level in Kannur district. The map showing as northern part of the area is higher amount than southern part in the study. This study concluded the turbidity is gradually decreased from north to south part of Kannur. The groundwater quality of $\mathrm{pH}$ range between $6.9-7.48$ and the groundwater is use to very suitable for the drinking purpose. Kannur district has not that much 
alkaline or acidic but in this area we observed in range from $6.99-7.5$, but this value also present in slightly basic in this study area.

Subsequently, the groundwater samples of this study area in permissible level of EC can be observed in the map of EC. Therefore the range of electrical conductivity is depending on the total dissolved solids and the comparison to the map of EC and TDS we can easily understand EC directly proportional to TDS. The total dissolved solids in water are due to the presence of sodium, potassium, calcium, magnesium, manganese, carbonates, bicarbonates, chlorides, phosphate, organic matter, and other particles. Most of the area the groundwater hardness is the property of water which prevents the lather formation with soap and increases the boiling points of water (Trivedy and Goel, 1986). The hardness of water mainly depends upon the amount of calcium or magnesium salts or both and the permissible limit of the hardness value is 300 . Here, the high range of the hardness value is 67. Therefore the hardness is very less in the Kannur district and the amount of permissible limit of bicarbonate also up to $180 \mathrm{mg} / \mathrm{l}$ in WHO, but BIS value is 30. In this study, we concluded the high amount of $\mathrm{HCO}_{3}{ }^{-}$in $\mathrm{Kannur}$ district, maximum range is 60 - 61.50 range of bicarbonate shown in northern part of the district. The southern part the district has been observed from the range between 40 - 50. Therefore the BIS range is greater than permissible limit in Kannur district.

The value of chloride for all the groundwater samples is ranged from $15.31-30.58 \mathrm{mg} / \mathrm{l}$. Most of the groundwater samples are indicated in chloride values within the acceptable limit $(250 \mathrm{mg} / \mathrm{l})$ of BIS and WHO standards. Chloride is the one of the most important parameter in assessing the water quality and higher concentration of chloride indicates higher degree of organic pollution. Kannur district has organic pollution is very less in this study. As for the permissible limit of chloride showing as map in result part. Nitrate and carbonate also presence in less amount in this district. The presence of nitrate in groundwater may be due to leaching of nitrate with the percolating water. The contamination of groundwater may be due to sewage and other wastes rich in nitrates and pollution also very less in the area.

The Calcium may dissolve readily from carbonate rocks and lime stones from soils. Nonetheless, the calcium is an essential nutritional element for human being and helps in the maintaining the structure of plant cells and soils. Sodium and potassium are naturally occurring elements in groundwater. These two elements are directly added into groundwater from 
industrial and domestic wastes and contribute salinity of water. The major source of potassium in natural fresh water is weathering of rocks but the quantities increase in the polluted water due to disposal of waste water. The chloride map showing that the amount of $\mathrm{Ca}, \mathrm{Mg}, \mathrm{Na}, \mathrm{K}$ are less amount in ground water and only minimum range is present in the water sample. According to the study, globally important groundwater resources have become under great risk due to the drastic increases in population, modern land use applications in agricultural and industrial. Demanding for the water supply which endanger both water quality and quantity. Assessing and monitoring the quality of groundwater is important to ensure sustainable safe and use of these resources for the various purposes.

From these outcomes it is determined that the discharge of untreated wastewater from area has affected the water quality. Heavy metals contamination may enter the food chain and cause various health problems. There is an urgent need to launch water management programs and policies and regular monitoring practices in the study area. GIS database for groundwater quality shall be developed and shared for effective management of this valuable resource. The present study to describe groundwater quality of Kannur district with a GIS perspective and georeferenced groundwater database and maps are developed which are useful for formulating sustainable groundwater use strategies.

\section{ACKNOWLEDGEMENT}

The authors acknowledge the Centre for water department and resource management (CWDRM), Kozhikode, Kerala, India source of provided data for their support and constructive suggestions. The authors are also acknowledging the Central University of Kerala, India for extending help during for this study.

\section{REFERENCES}

1. Ahn $\mathrm{H}$, Chon $\mathrm{H}$, “Assessment of groundwater contamination using geographic information systems”, Environ. Geochem. Health, 21: pp. 273-289, 1999.

2. APHA, "Standard methods for the Examination of Water and wastewater", $19^{\text {th }}$ edn. American Public Health Association, Washington DC, 1995. 
3. Asadi SS, Vuppala P, Reddy M A, Remote sensing and GIS techniques for evaluation of groundwater quality in Municipal Corporation of Hyderabad (Zone-V), India. Int. J. Environ. Res. Public Health, 4(1): pp. 45-52, 2007.

4. Babiker I S, Mohamed AM, Hiyama T "Assessing groundwater quality using GIS", Water Resour. Manage. 21(4): 699 -715, 2007.

5. Barber C, Otto CJ, Bates LE, Taylor K J, Evaluation of the relationship between land-use changes and groundwater quality in a water-supply catchment, using GIS technology: the Gwelup Wellfield, Western Australia. J. Hydrogeol., 4(1): pp. 6-19, 1996.

6. Barker, A. P. Newton R. J. and Bottrell, S. H, "Processes Affecting Groundwater Chemistry in a Zone of Saline Intrusion into an Urban Sandstone Aquifer", Applied Geochemistry, Vol. 13, No. 6, pp. 735-749, 1998.

7. Butler M, Wallace J, Lowe M, “Ground-water quality classification using GIS contouring methods for Cedar Valley, Iron County, Utah. In: Digital mapping techniques”, Workshop Proceedings, US Geological Survey Open-File Report 02-370, 2002.

8. CGWB, Ground Water Information Booklet of Kannur District, Kerala State, Government of India Ministry of water resources, 2007.

9. Chrisman N, "Exploring Geographic Information Systems", John Kliley and Sons, New York, 1997.

10. Dethier, D. P, A hydrochemical model for stream chemistry, cascade range, Washington U.S.A. Earth Surface Processes Land Forms, 13: 321-333, 1998.

11. Faure, G. Principles and applications of geochemistry, $2^{\text {nd }}$ ed. Englewood Cliffs, NJ: Prentice-Hall, 1998.

12. Goodchild M F, The state of GIS for environmental problem solving. In: Goodchild MF, Parks BO, Steyart LT (eds) Environmental modeling with GIS. Oxford University Press, New York, pp. 8-15, 1993.

13. Ground Water Resources of Tamil Nadu, Public Works Department. Government of Tamil Nadu, 2002. 
14. Jamal Hassan,. "A Geostatistical approach for mapping groundwater quality (Case Study: Tehsil Sheikhupura)”, International Journal of Science and Research, Volume 3, pp. 239$245,2014$.

15. Kharad SM, Rao KS, Rao GS, (1999). GIS based groundwater assessment model, GIS@development, Nov-Dec 1999. http://www.gisdevelopment. net/application/nrm/ water/ground/watg0001.htm. Accessed 22 June 2010.

16. Mouna, K.R., Moncef, G. and Rachida B, (2011). Use of Geographical Information System and Water Quality Index to Assess Groundwater Quality in El Khairat Deep Aquifer (Enfidha, Tunisian Sahel). Iranica Journal Energy and Environment, 2 (2), pp.133-144.

17. Nas B, Berktay A, (2006). Groundwater contamination by nitrates in the City of Konya, (Turkey): A GIS perspective. J. Environ. Manage., 79(1): pp 30-37.

18. Prasad K, (2008). Institutional Framework for Regulating Use of Ground Water in India, Central Ground Water Board, Ministry of Water Resources, Government of India, http://cgwb.gov.in/INCGW/Kamta\%20Prasad\%20report.pdf, Accessed 28 September 2011.

19. Singh D S H, Lawrence J F, (2007). Groundwater quality assessment of shallow aquifer using geographical information system in part of Chennai city Tamilnadu. J. Geol. Soc. India, 69: pp, 1067-1076.

20. Sudha Menon, (2007). Ground Water Management: Need for Sustainable Approach, ICFAI BUSINESS SCHOOL, Munich.

21. Thangavelu, A (2014). "Mapping the groundwater quality in Coimbatore city, India based on physico-chemical parameters", IOSR Journal of Environmental Science, Toxicology and Food Technology, vol 3, no.4, pp. 32-40.

22. Tomlin K R (1990). "Geographic Information Systems and Cartographic Modeling", Englewood, Cliffs, Prentice Hall NJ,

23. Trivedy R. K. and Goel P. K, (1986). "Chemical and Biological methods for water pollution Studies", Environmental Publication, pp. 42-50.

24. World Health Organization (WHO) (1993). "Guidelines for drinking water quality-I, Recommendations" $2^{\text {nd }}$ Ed. Geneva. 
25. Umar, R., Muqtada, M., Khan, A. and Absar, A. (2006). Groundwater hydrochemistry of a sugarcane cultivation belt in parts of Muzaffarnagar district, Uttar Pradesh, India. Environmental Geology, 49: 999 - 1008.

26. World Health Organization (2008), “Guidelines for drinking-water quality”. Third edition.

27. Yammani, S (2007). "Groundwater Quality Suitable Zones Identification: Application of GIS, Chittoor Area, Andhra Pradesh, India,” Environmental Geology, Vol. 53, No. 1, 2007, pp. 201-210,

28. Zektser I S (2000). "Groundwater and the environment: Applications for the global community", Boca Raton: Lewis. p. 175. 